\title{
GENERAL CHARACTERISTICS OF JUDICIAL INTERROGATIONS IN THE CRIMINAL PROCESS OF UKRAINE
}

\section{Valeria Chernetska ${ }^{1}$}

DOI: https://doi.org/10.30525/978-9934-26-050-6-28

Interrogation is a procedural action that is regulated by criminal procedural norms, the information and psychological process of communication of persons taking part in it, and is aimed at obtaining information about the facts known to the interrogated that are important for establishing the truth in the case. Interrogation is the most common way to obtain evidence. At the same time, interrogation is one of the most difficult judicial actions; its implementation requires from the investigator a high general and professional culture, deep knowledge of human psychology. The purpose of the interrogation is to obtain complete and objective evidence of the reality. These testimonies are the source of evidence, and the factual data contained in them is evidence. That is why interrogation as a judicial procedural action should be considered from different angles, including, taking into account the various types of judicial interrogation in criminal proceedings.

Dependent on the procedural position of the interrogated in court, interrogations are distinguished:

a) the accused. A feature of the interrogation of the accused in court is that it differs significantly from his interrogation during the pre-trial investigation, since the number of persons taking part in the interrogation of the accused

\footnotetext{
${ }^{1}$ National University «Odessa Law Academy», Ukraine
} 
increases, most of them are thoroughly familiar with the materials of the criminal proceedings and the indictment, all this takes place in public and the openness of the trial, and at the same time the accused himself gets the right to interrogate other participants in the trial, to participate in the trial.

b) the victim. The rules for interrogating the victim are regulated by Art. 53 of the Criminal Procedure Code of Ukraine, which stipulates that before interrogating the victim, the presiding judge establishes information about his identity and clarifies the relationship between the victim and the accused. In addition, he finds out whether the victim received a monument about the rights and obligations of the victim, they are clear to him, and if necessary, explains them, and also warns of criminal liability for knowingly false testimony. In this regard, it should be noted that the victim is not warned of criminal liability for refusing to testify, since in paragraph 1 of Part 1 of Art. 56 of the Code of Criminal Procedure of Ukraine, he is entitled to give explanations, testimonies or refuse to give them.

c) a witness. To organize the interrogation of a witness during the trial, you need to clearly understand how to plan and systematize specific actions during the trial for an objective and comprehensive consideration of the case in court. According to A. Konovalov, interrogations, which do not provide for a specific plan, take place passively, by gravity, without proper focus [1, p. 84]. As practice shows, in most cases the testimony that is provided when a case is considered in court is very different from the primary testimony of witnesses, and for this it is necessary for law enforcement officials to pay more attention and carefully to the initial investigative actions. When interrogating a witness, the most difficult task is to establish the reliability of his testimony, because there is a possibility that the testimony may be knowingly false if there is a personal interest, sympathy for the accused or the victim, blackmail and threats from interested parties. In this regard, one must agree with the opinion of V. Shepitko that interrogation is one of the most difficult actions, the conduct of which requires a high general and professional culture, a deep knowledge of human psychology [2, p. 158].

d) interrogation of an expert. One of the ways to check the reliability of an expert's conclusion in criminal proceedings is to interrogate an expert. Requirements regarding the interrogation of an expert at the stage of pre-trial investigation are not given in the Criminal Procedure Code of Ukraine. So, it is conducted according to the general rules of interrogation (Articles 223, 224 of the Criminal Procedure Code of Ukraine). The procedural order and the subject of the expert's interrogation in court is determined by Article 356 of the Criminal Procedure Code of Ukraine. Circumstances about which an expert can be questioned (part 3 of article 356 of the Criminal Procedure Code of Ukraine) can be conditionally divided into the following groups: 
1) circumstances that determine the competence and competence of an expert - special knowledge and qualifications on the issues under study (education, work experience, scientific degree, etc.), relate to the subject of his examination; used methods and theoretical developments; the applicability and correctness of the application of principles and methods to the facts of criminal proceedings; other issues related to the reliability of the report; 2) the quality of the materials provided to the expert - the sufficiency of the information on the basis of which the conclusion was prepared [3, p. 328].

In addition, depending on the age characteristics of the interrogated person, judicial interrogation is subdivided into: a) minor; b) a minor; c) an adult; c) elderly people.

Depending on the deviant personality traits of the person being interrogated: a) interrogation of habitual (without deviant qualities of people; b) interrogation of persons who have committed a recurrence of crimes, c) interrogation of persons with mental disabilities, alcoholics, drug addicts, etc.; d) interrogation of convicts held in places of serving sentences; e) interrogation of foreigners or persons with a special regulatory and witness status.

According to the sequence of carrying out: a) primary; b) repeated.

In terms of clarification of issues: a) main; b) additional.

Depending on the type of testimony of the interrogated person: a) interrogation of the person, gives objectively reflecting the validity of the testimony; b) interrogation of a person, gives false testimony; c) interrogation of a person, gives deliberately false testimony.

On the subject of proof: a) interrogation of the person, confirms the prosecution's version; b) interrogation of the person, refutes (denies) the prosecution's version.

According to the situation during interrogation: a) interrogation in a conflict-free situation; b) interrogation in a conflict situation.

In addition, solely as for judicial proceedings, there are grounds for distinguishing the following subspecies of judicial interrogation: direct (main), cross, chess (simultaneous) and combined interrogation.

Despite the fact that the issue of direct and cross-examination is regulated only by the position of ch. 6-8 st. 352 and Art. 353 of the Code of Criminal Procedure, according to these norms, there is a real revolution in the interrogation of witnesses and victims, which must now be carried out according to completely new standards.

We, through a systemic interpretation of the norms of the Criminal Procedure Code and using an analogy, note that the victim and the accused, in principle, can also be questioned under the rules of cross-examination. However, one should not forget that the victim, like the accused, has the right to refuse to testify. According to the logic of the law, he can exercise this right 
at any time of production. Therefore, there is nothing to prevent these individuals from refusing to be cross-examined.

\section{References:}

1. Konovalova V.A. (1965) Problems of logic and psychology in modern tactics. Kharkov, p. 140.

2. Shepitko Y.V. (2002) Theory of criminalistic tactics. Kharkiv: Grif, 349 p.

3. Babunich V. (2011) The essence and meaning of cross-examination. Procedural features of cross-examination when considering criminal cases in court. Bulletin of the Ivan Franko National University of Lviv. Legal series. Issue 53. P. 322-328. 